\title{
THE INFLUENCE OF DIETARY CARBOHYDRATE DEPRIVATION \\ ON THE METABOLISM OF INTRAVENOUSLY ADMINISTERED FRUCTOSE AND GLUCOSE IN MAN 1,
}

\author{
By JAMES W. CRAIG, MAX MILLER, MALCOLM S. MACKENZIE, AND \\ HIRAM WOODWARD, JR. \\ (From the Department of Medicine, School of Medicine, Western Reserve University, \\ Cleveland, Ohio)
}

(Submitted for publication April 22, 1957; accepted May 23, 1957)

The phenomenon of starvation diabetes or the induction of impaired carbohydrate tolerance by the restriction of dietary carbohydrate has been recognized for almost a century. Peters (1) reviewed the subject comprehensively in 1945 . The effect of carbohydrate deprivation upon the changes in the total blood sugar concentration following fructose administration has been investigated previously in animals $(2-4)$ and in a human subject (5). Since the blood levels of glucose and fructose were not determined separately, it is not possible to ascertain from the results of these studies the effect of carbohydrate deprivation upon the fructose tolerance curve. Potick (6) measured both the total blood sugar and blood fructose concentrations in the dog following fructose administration; decreasing the carbohydrate content of the diet did not produce a significant alteration in either the fructose or total sugar curves. However, most workers in the field have been concerned with the effect of dietary alterations on glucose tolerance alone, and the phenomenon of starvation diabetes has usually been considered only in terms of altered glucose metabolism.

It has been demonstrated that the metabolic pathways of glucose and fructose are different (7-9) and that administered fructose may be removed from the blood at a normal rate in certain clinical conditions in which glucose tolerance is impaired, such as diabetes mellitus (10), cortisone administration (11), and the stresses of surgery (12), anesthesia (13), and infection (14). These considerations and the results of Potick (6) men-

\footnotetext{
1 These studies were supported in part by a grant (A376) from the United States Public Health Service, National Institute of Arthritis and Metabolic Diseases.

2 A preliminary report of this work was presented to the Midwestern Section of the American Federation for Clinical Research, Chicago, Illinois, October 29, 1953.
}

tioned above suggested that a similar discrepancy between glucose and fructose metabolism might exist in otherwise normal subjects who were deprived of dietary carbohydrate.

Accordingly, the present studies were designed to compare the effect of dietary carbohydrate deprivation upon intravenous glucose and fructose tolerance in normal human subjects. The results of such a study might yield information regarding the site of the metabolic defect in starvation diabetes.

\section{EXPERIMENTAL PROCEDURES}

Six healthy male physicians or medical students, whose ages ranged from 24 to 27 years, were the subjects for these experiments.

Control intravenous glucose tolerance tests were performed on each subject at a time when he had been eating a normal unrestricted diet and had been receiving an oral multivitamin preparation. ${ }^{3}$ Four of the subjects then fasted from the evening of one day until the morning of the third subsequent day, when the glucose tolerance test was repeated in a comparable manner. The period of fasting preceding the second test varied from 55 to 60 hours. The intake of water was not restricted and all of the subjects except F.P. received oral multivitamin supplements during this period. Instead of fasting, subjects A.M. and W.C. ate a carbohydrate-free diet consisting of only meat and butter for two days; the glucose tolerance test was repeated on the morning of the third day. Subject A.M. consumed 268 grams of protein and 80 grams of fat each day, while W.C. ate 149 grams of protein and 35 grams of fat daily. They also received oral multivitamin supplements.

At another time control intravenous fructose tolerance tests were performed in the same subjects. After each individual had been subjected to the same form of dietary carbohydrate deprivation, either fasting or a meat diet, for the same period of time as described above, the fructose tolerance test was repeated. In two cases the fruc-

\footnotetext{
${ }^{3}$ Avicap ${ }^{\circledR}$ capsules furnished by Burroughs Wellcome \& Company and Stuart Formula tablets supplied by the Stuart Company were used in this study.
} 
tose tolerance tests were performed before the glucose tests.

The hexose tolerance tests were performed in the postabsorptive state with the subject resting in the recumbent position. One gram of glucose or fructose ${ }^{4}$ per $\mathrm{Kg}$. of body weight was administered intravenously in one hour. A 10 per cent solution of the hexose in water was used and an infusion pump was employed to insure a uniform rate of administration. Blood samples were obtained through an indwelling needle in an antecubital vein before and at 30 minute intervals after the start of hexose infusion for a total of three hours. The blood samples were analyzed for the following substances by the methods listed:

\section{Glucose or total \\ hexose \\ Fructose}

Pyruvic acid

Citric acid

Malic acid

Inorganic

phosphorus

Ketone bodies
Somogyi-Nelson (15)

Roe, as modified by Higashi and Peters (16)

Friedemann and Haugen (17)

Natelson, Pincus, and Lugovoy and Taussky and Shorr (19)

Hummel (20)

Fiske and Subbarow (21)

Eichler and Hindemith (22), modified.

Blood for fructose determination was treated with glucose oxidase before precipitation in order to reduce the concentration of blood glucose to a level at which it did not interfere with the measurement of fructose. In the fructose experiments, the blood glucose level was computed by subtracting the fructose concentration from the total hexose concentration as measured by the Somogyi-Nelson method.

An additional experiment was performed to aid in the assessment of the significance of changes in the concentrations of blood glucose, pyruvic acid, citric acid, malic acid, and plasma inorganic phosphorus. The subjects for this experiment were four male patients whose ages ranged from 52 to 63 years. All four were convalescent from myocardial infarctions which had occurred from 6 to 23 days previously and all were receiving dicumarol anticoagulant therapy. One of these patients had a diabetic-type glucose tolerance curve, but his fasting blood glucose concentration varied from 82 to $89 \mathrm{mg}$. per 100 $\mathrm{ml}$. With the subject at rest following an overnight fast, peripheral venous blood samples were obtained through an indwelling needle at 30 minute intervals for three hours. No procedure other than the drawing of the blood samples was performed during this period. The samples were analyzed for the substances listed above, and the results are shown in Table I. The mean concentration represents the average of all 28 determinations of a substance in the four patients, and the pooled standard deviation was calculated from the sum of the squared

4 The fructose solutions used in this study were supplied by Mead Johnson \& Company.
TABLE I

\begin{tabular}{lcc}
$\begin{array}{c}\text { Variations in concentrations of substances in peripheral venous } \\
\text { blood specimens obtained at thirty minute intervals for } \\
\text { three hours from four subjects in the basal state }\end{array}$ \\
\hline \multicolumn{4}{c}{ Substance } & $\begin{array}{c}\text { Mean } \\
\text { concentration* }\end{array}$ & $\begin{array}{c}\text { Pooled } \\
\text { standard } \\
\text { deviation }\end{array}$ \\
\hline & \multicolumn{2}{c}{$(m g$. per 100 ml.) } \\
Blood glucose & 79 & \pm 2.9 \\
Blood pyruvic acid & 0.86 & \pm 0.15 \\
Blood citric acid & 2.1 & \pm 0.14 \\
Blood malic acid & 0.20 & \pm 0.017 \\
Plasma inorganic phosphorus & 3.3 & \pm 0.43
\end{tabular}

* Average of 28 determinations.

deviations from the mean of each of the four cases. In a similar experiment which has been reported previously (10), the following mean concentrations and pooled standard deviations were obtained in four normal male subjects : glucose, $86 \pm 3.3$; pyruvic acid, $0.74 \pm 0.16$; and citric acid, $1.8 \pm 0.16 \mathrm{mg}$. per $100 \mathrm{ml}$. These results correspond closely to those obtained in the current experiment. When fructose was added to human blood to final concentrations varying between 1.9 and $78 \mathrm{mg}$. per 100 ml., recoveries within \pm 2 per cent of the amount added were obtained by the fructose method described above. In a previous study the mean fasting blood fructose concentration in 17 non-diabetic subjects was found to be $1.7 \pm 1.6 \mathrm{mg}$. per $100 \mathrm{ml}$. The blood ketone body concentration in normal subjects after an overnight fast is usually less than $1 \mathrm{mg}$. per $100 \mathrm{ml}$. by the method used in this study.

The " $t$ " test of Fisher was used to assess the statistical significance of differences between mean values obtained in tests performed after the subjects had been eating a mixed diet and corresponding values after carbohydrate deprivation.

RESULTS

\section{Weight loss}

The fasting subjects lost from four to eight pounds during the two day period without food. One of the subjects on the meat diet lost one and one-half pounds, but the weight of the second subject was not altered.

\section{Ketosis}

The fasting subjects showed a strongly positive qualitative test for ketone bodies in the urine at the end of the fasting period. In subject R.B., blood ketones were $41 \mathrm{mg}$. per $100 \mathrm{ml}$. after the first two day period of fasting and $31 \mathrm{mg}$. per $100 \mathrm{ml}$. after his second fast; blood ketones were not measured in the other fasting subjects. After the 
TABLE II

Influence of dietary carbohydrate deprivation on blood glucose and fructose concentrations following intravenous administration of hexoses in normal subjects

\begin{tabular}{|c|c|c|c|c|c|c|c|c|c|c|c|c|c|c|c|c|c|}
\hline \multirow{4}{*}{$\begin{array}{l}\text { Sub- } \\
\text { ject }\end{array}$} & \multirow[b]{4}{*}{ Wt. } & \multirow[b]{4}{*}{ Date } & \multirow{4}{*}{$\begin{array}{c}\text { Previous } \\
\text { diet }\end{array}$} & \multicolumn{7}{|c|}{ Blood glucose (mg./100 ml.) } & \multicolumn{7}{|c|}{ Blood fructose ( $\mathrm{mg} . / 100 \mathrm{ml}$. ) } \\
\hline & & & & \multirow{3}{*}{$\begin{array}{l}\text { Initial } \\
\text { concen- } \\
\text { tration }\end{array}$} & \multicolumn{6}{|c|}{ Change from initial concentration } & \multirow{3}{*}{$\begin{array}{l}\text { Initial } \\
\text { concen- } \\
\text { tration }\end{array}$} & \multirow{2}{*}{\multicolumn{6}{|c|}{$\frac{\text { Change from initial concentration }}{\text { Minutes after start of infusion }}$}} \\
\hline & & & & & \multicolumn{6}{|c|}{ Minutes after start of infusion } & & & & & & & \\
\hline & & & & & 30 & 60 & 90 & 120 & 150 & 180 & & 30 & 60 & 90 & 120 & 150 & 180 \\
\hline & $K g$. & & & & & & & & & & & & & & & & \\
\hline \multicolumn{18}{|c|}{ After glucose ( $1 \mathrm{Gm} . / \mathrm{Kg}$. in $1 \mathrm{hr}$.) } \\
\hline F. P. & 94 & $11 / 21 / 52$ & Mixed & 98 & +193 & +302 & +150 & +55 & -2 & -26 & & & & & & & \\
\hline R. B. & 87 & $12 / 9 / 52$ & Mixed & 125 & +193 & +192 & +37 & -7 & -48 & -64 & & & & & & & \\
\hline J. W. & 75 & $11 / 18 / 53$ & Mixed & 95 & +162 & +224 & +77 & +8 & -42 & -33 & & & & & & & \\
\hline R. W. & 92 & $12 / 14 / 53$ & Mixed & 93 & +216 & +225 & -27 & -68 & -36 & -31 & & & & & & & \\
\hline A. $\mathrm{M}$. & 64 & $12 / 13 / 52$ & Mixed & 99 & +145 & +234 & +70 & -12 & -42 & -27 & & & & & & & \\
\hline W. C. & 86 & $1 / 10 / 53$ & Mixed & 91 & +171 & +247 & +81 & -8 & -42 & -34 & & & & & & & \\
\hline Mean & & & & 100 & +180 & +237 & +65 & -5 & -35 & -36 & & & & & & & \\
\hline F. P. & & $11 / 24 / 52$ & Fasting & 68 & +200 & +353 & +294 & +214 & +126 & +65 & & & & & & & \\
\hline R. B. & & $12 / 12 / 52$ & Fasting & 74 & +245 & +413 & +241 & +164 & +107 & +62 & & & & & & & \\
\hline J. W. & & $12 / 1 / 53$ & Fasting & 68 & +208 & +320 & +244 & +167 & +110 & +73 & & & & & & & \\
\hline R. W. & & $12 / 17 / 53$ & Fasting & 71 & +217 & +300 & +152 & +77 & +25 & +4 & & & & & & & \\
\hline A. $\mathrm{M}$. & & $12 / 16 / 52$ & No CHO & 75 & +208 & +278 & +156 & +58 & +24 & -11 & & & & & & & \\
\hline W. C. & & $1 / 14 / 53$ & No $\mathrm{CHO}$ & 68 & +206 & +330 & +252 & +174 & +119 & +25 & & & & & & & \\
\hline Mean & & & & 71 & +214 & +332 & +223 & +142 & +85 & +36 & & & & & & & \\
\hline \multicolumn{18}{|c|}{ After fructose ( $1 \mathrm{Gm} . / \mathrm{Kg}$. in $1 \mathrm{hr}$.) } \\
\hline F. P. & & $12 / 3 / 52$ & Mixed & 89 & +11 & +10 & +2 & +2 & -10 & +1 & 7 & +72 & +81 & +14 & +3 & $\mathbf{0}$ & -3 \\
\hline R. B. & & $12 / 27 / 52$ & Mixed & 100 & -22 & -1 & -13 & -8 & -15 & -10 & $<1$ & +64 & +78 & +28 & +12 & +7 & +4 \\
\hline J. W. & & $12 / 15 / 53$ & Mixed & 78 & +1 & +34 & -3 & -24 & -19 & -6 & 1 & +73 & +76 & +24 & +9 & +3 & +4 \\
\hline R. W. & & $1 / 26 / 54$ & Mixed & 86 & +19 & +33 & -16 & -40 & -30 & -14 & 3 & +96 & +99 & +38 & +10 & +4 & +2 \\
\hline A. M. & & $11 / 28 / 52$ & Mixed & 75 & -11 & +8 & -18 & -15 & -12 & -8 & 2 & +86 & +94 & +28 & +13 & +8 & +3 \\
\hline w. c. & & $12 / 17 / 52$ & Mixed & 66 & +14 & +53 & +21 & -5 & +2 & -2 & 2 & +89 & +88 & +31 & +13 & +3 & +3 \\
\hline Mean & & & & 82 & +2 & +23 & -4 & -15 & -14 & -6 & 3 & +80 & +86 & +27 & +10 & +4 & +2 \\
\hline F. P. & & $12 / 6 / 52$ & Fasting & 72 & +17 & +29 & +22 & +24 & +25 & +17 & $<1$ & +90 & +86 & +25 & +12 & +4 & +3 \\
\hline R. B. & & $12 / 31 / 52$ & Fasting & 60 & +34 & +46 & +45 & +27 & +19 & +23 & 3 & +98 & +83 & +27 & +12 & +4 & +2 \\
\hline J. W. & & $12 / 18 / 53$ & Fasting & 68 & +8 & +38 & +32 & +18 & +6 & +2 & 1 & +59 & +76 & +27 & +10 & +5 & +2 \\
\hline R. W. & & $1 / 29 / 54$ & Fasting & 76 & +3 & +26 & +23 & +9 & +9 & -1 & 2 & +73 & +87 & +26 & +14 & +4 & +3 \\
\hline A. M. & & $12 / 1 / 52$ & No $\mathrm{CHO}$ & 70 & +44 & +38 & +35 & +29 & +5 & +9 & 2 & +71 & +86 & +31 & +12 & +6 & +2 \\
\hline w. C. & & $12 / 20 / 52$ & No $\mathrm{CHO}$ & 58 & +24 & +41 & +24 & +18 & +16 & +12 & 3 & +95 & +78 & +27 & +10 & +4 & +3 \\
\hline Mean & & & & 67 & +21 & +36 & +30 & +21 & +13 & +10 & 2 & +81 & +83 & +27 & +12 & +4 & +2 \\
\hline
\end{tabular}

meat diet, one subject had a blood ketone level of $8 \mathrm{mg}$., and the other had a concentration of $26 \mathrm{mg}$. per $100 \mathrm{ml}$. on one occasion and $10 \mathrm{mg}$. per $100 \mathrm{ml}$. after the second dietary period.

\section{Concentrations of metabolites in blood or plasma in postabsorptive state}

These data are included in Tables II, III, and IV. In every instance carbohydrate deprivation for two days resulted in a decrease in the fasting blood glucose concentration; the average control value plus or minus one standard deviation was $91 \pm 15$ mg. per $100 \mathrm{ml}$., as compared to $69 \pm 6 \mathrm{mg}$. per 100 $\mathrm{ml}$. after dietary restriction $(\mathrm{p}<0.01)$. In 9 out of 12 instances, the fasting blood pyruvic acid concentration was higher after carbohydrate deprivation; the average control value was $1.0 \pm 0.2 \mathrm{mg}$. per $100 \mathrm{ml}$. and the average after dietary restriction was $1.2 \pm 0.2 \mathrm{mg}$. per $100 \mathrm{ml} .(\mathrm{p}<0.05)$. Similarly, the average fasting plasma citric acid level was higher $(2.2 \pm 0.3 \mathrm{mg}$. per $100 \mathrm{ml}$.) after dietary restriction than before $(1.8 \pm 0.4 \mathrm{mg}$. per $100 \mathrm{ml}$.) ; such a difference was seen in 10 of 11 instances, $p<0.02$. Reduction of the quantity of dietary carbohydrate did not produce a consistent alteration in the fasting concentration of blood malic acid or plasma inorganic phosphorus.

Since the results of the hexose tolerance tests in the subjects who fasted were similar to those obtained in subjects on the meat diet, they will not be described separately but will be considered as one group. The data are contained in Tables II, III, and IV, and the tolerance curves are shown in Figure 1. 


\section{Glucose tolerance tests}

During the control tests the blood glucose concentration rose to an average of $237 \pm 36 \mathrm{mg}$. per $100 \mathrm{ml}$. above the initial level and returned to or below the initial level in 120 minutes, except in the cases of F.P. and J.W., in which the initial concentration was not attained until 150 minutes. In the tests performed in the same subjects after two days of dietary carbohydrate deprivation, the maximum glucose rise exceeded $(p<0.01)$ that of the control test in all six cases. The maximum rises exceeded those of the control tests by 44 to 221 $\mathrm{mg}$. per $100 \mathrm{ml}$. and the average maximum rise above the initial level was $332 \pm 47 \mathrm{mg}$. per 100 ml. From 60 through 180 minutes the blood glucose concentrations were consistently higher than in the control tests, and in only two cases had the blood glucose concentration returned to the initial level in 180 minutes.

During the control tests all the subjects showed a rise in blood pyruvic acid concentration which varied from 0.2 to $1.5 \mathrm{mg}$. per $100 \mathrm{ml}$. and averaged $0.5 \pm 0.5 \mathrm{mg}$. per $100 \mathrm{ml}$. After dietary restriction the average increase in blood pyruvic acid was only $0.2 \pm 0.2 \mathrm{mg}$. per $100 \mathrm{ml}$. with a variation from 0 to $0.6 \mathrm{mg}$. per $100 \mathrm{ml}$. The difference between the mean blood pyruvic acid rises before and after dietary carbohydrate restriction did not prove to be statistically significant $(p>0.2)$.

When glucose was given, the concentration of the blood citric acid decreased slightly in five of the six subjects. Carbohydrate deprivation did not alter this response significantly; when the mean changes in blood citric acid concentration

TABLE III

Influence of carbohydrate deprivation on blood pyruvic acid and citric acid concentrations following intravenous administration of hexoses in normal subjects

\begin{tabular}{|c|c|c|c|c|c|c|c|c|c|c|c|c|c|c|c|}
\hline \multirow{4}{*}{$\begin{array}{l}\text { Sub- } \\
\text { ject }\end{array}$} & \multirow{4}{*}{$\begin{array}{l}\text { Previous } \\
\text { diet }\end{array}$} & \multicolumn{7}{|c|}{ Blood pyruvic acid (mg./100 ml.) } & \multicolumn{7}{|c|}{ Blood citric acid (mg./100 ml.) } \\
\hline & & \multirow{3}{*}{$\begin{array}{l}\text { Initial } \\
\text { concen- } \\
\text { tration }\end{array}$} & \multirow{2}{*}{\multicolumn{6}{|c|}{$\begin{array}{c}\text { Change from initial concentration } \\
\text { Minutes after start of infusion }\end{array}$}} & \multirow{2}{*}{\multicolumn{7}{|c|}{$\begin{array}{l}\text { Change from initial concentration } \\
\text { Minutes after start of infusion }\end{array}$}} \\
\hline & & & & & & & & & & & & & & & \\
\hline & & & 30 & 60 & 90 & 120 & 150 & 180 & tration & 30 & 60 & 90 & 120 & 150 & 180 \\
\hline \multicolumn{16}{|c|}{ After glucose $(1 \mathrm{Gm} . / \mathrm{Kg}$. in $1 \mathrm{hr}$.) } \\
\hline F. P. & Mixed & 0.8 & 0 & +0.2 & +0.6 & +0.5 & & +0.1 & 1.6 & +0.3 & +0.2 & +0.2 & +0.1 & & -0.1 \\
\hline R. B. & Mixed & 0.9 & +1.1 & +1.5 & +1.0 & +0.3 & 0 & -0.2 & 2.2 & 0 & -0.1 & -0.1 & -0.1 & -0.5 & -0.5 \\
\hline J. W. & Mixed & 1.1 & +0.2 & +0.1 & +0.1 & -0.1 & -0.2 & +0.1 & 2.6 & -0.2 & -0.2 & 0 & & & \\
\hline R. W. & Mixed & 0.9 & -0.4 & +0.4 & -0.3 & 0 & +0.3 & +0.5 & 2.0 & -0.2 & -0.1 & 0 & & -1.0 & -0.1 \\
\hline A. $\mathbf{M}$. & Mixed & 0.9 & -0.1 & +0.3 & +0.3 & 0 & -0.1 & -0.3 & 2.1 & -0.1 & -0.1 & -0.1 & -0.1 & & -0.5 \\
\hline w. C. & Mixed & 1.2 & +0.2 & 0 & +0.2 & +0.1 & -0.5 & -0.5 & 1.5 & -0.1 & $\mathbf{0}$ & +0.2 & 0 & -0.2 & -0.2 \\
\hline Mean & & 1.0 & +0.2 & +0.4 & +0.3 & +0.1 & -0.1 & -0.1 & 2.0 & $\mathbf{0}$ & -0.1 & $\mathbf{0}$ & $\mathbf{0}$ & -0.6 & -0.3 \\
\hline F. P. & Fasting & 1.2 & +0.4 & +0.3 & +0.1 & 0 & +0.2 & +0.4 & 2.0 & +0.1 & +0.2 & & o & +0.2 & -0.1 \\
\hline R. B. & Fasting & 1.2 & -0.1 & +0.1 & +0.2 & 0 & 0 & -0.3 & 2.6 & $\mathbf{0}$ & -0.2 & +0.2 & -0.2 & -0.2 & -0.4 \\
\hline J.W. & Fasting & 1.2 & +0.1 & +0.2 & -0.4 & +0.5 & +0.5 & +0.6 & 2.8 & -0.4 & -0.3 & -0.4 & -0.4 & -0.7 & -0.3 \\
\hline R. W. & Fasting & 1.3 & -0.2 & -0.1 & 0 & +0.3 & +0.4 & 0 & 2.6 & -0.3 & -0.2 & -0.2 & -0.1 & -0.5 & -0.1 \\
\hline A. $\mathbf{M}$. & No $\mathrm{CHO}$ & 1.5 & -0.2 & 0 & 0 & -0.1 & 0 & -0.3 & 2.1 & -0.1 & -0.4 & -0.2 & -0.6 & -0.6 & -0.7 \\
\hline w. C. & No CHO & 0.9 & +0.6 & +0.4 & +0.3 & +0.3 & +0.3 & & 1.8 & -0.1 & -0.1 & -0.5 & -0.5 & -0.6 & -0.5 \\
\hline Mean & & 1.2 & +0.1 & +0.2 & 0 & +0.2 & +0.2 & +0.1 & 2.3 & -0.1 & -0.2 & -0.2 & -0.3 & -0.4 & -0.4 \\
\hline \multicolumn{16}{|c|}{ After fructose $(1 \mathrm{Gm} . / \mathrm{Kg}$. in $1 \mathrm{hr})}$. \\
\hline F. P. & Mixed & 1.0 & +1.8 & +2.6 & +0.9 & +0.3 & +0.6 & +0.4 & 1.4 & +0.2 & +0.5 & +0.4 & +0.2 & & -0.2 \\
\hline R. B. & Mixed & 1.5 & -0.1 & +1.3 & +0.5 & +0.5 & +0.3 & -0.2 & 1.6 & +1.0 & +0.6 & +0.8 & +0.5 & +0.4 & +0.4 \\
\hline J. W. & Mixed & 0.9 & +0.9 & +1.3 & +0.5 & +0.1 & -0.1 & -0.1 & & & & & & & \\
\hline R. W. & Mixed & 0.8 & +1.2 & +1.1 & +0.4 & -0.1 & -0.2 & -0.2 & 2.0 & +0.1 & +0.1 & +0.4 & 0 & -0.2 & -0.4 \\
\hline A. $\mathbf{M}$. & Mixed & 1.0 & +1.1 & +0.9 & +0.1 & +0.4 & +0.4 & -0.1 & 1.6 & +0.2 & +0.3 & +0.4 & +0.3 & & -0.2 \\
\hline w. C. & Mixed & 1.4 & +1.0 & +1.3 & +0.5 & -0.4 & -0.8 & -0.3 & 1.6 & +0.1 & +0.4 & +0.3 & +0.2 & -0.3 & -0.3 \\
\hline Mean & & 1.1 & +1.0 & +1.4 & +0.5 & +0.1 & 0 & -0.1 & 1.6 & +0.3 & +0.4 & +0.5 & +0.2 & o & -0.1 \\
\hline F. P. & Fasting & 1.2 & +0.5 & +1.7 & +0.7 & +0.2 & 0 & -0.1 & 1.8 & 0 & -0.2 & +0.1 & +0.4 & & 0 \\
\hline R. B. & Fasting & 1.1 & +1.7 & +2.7 & +1.9 & +0.7 & +0.4 & +0.1 & 2.1 & $\mathbf{0}$ & +0.5 & +0.4 & +0.3 & -0.2 & +0.1 \\
\hline J.W. & Fasting & 1.4 & +0.5 & +2.0 & +1.0 & +1.1 & +0.4 & +0.1 & & & & & & & \\
\hline R. W. & Fasting & 1.2 & +0.7 & +2.1 & +1.8 & +0.6 & +0.4 & +0.1 & 2.5 & +0.2 & & +0.4 & +0.6 & +0.3 & +0.1 \\
\hline A. $\mathbf{M}$. & No CHO & 1.3 & +1.0 & +1.6 & +0.3 & 0 & +0.2 & -0.5 & 2.3 & +0.1 & -0.1 & -0.1 & -0.2 & & -0.6 \\
\hline w. C. & No CHO & 1.2 & +1.2 & +1.7 & +1.1 & +0.2 & -0.1 & -0.4 & 2.1 & 0 & +0.2 & +0.2 & +0.2 & -0.2 & -0.4 \\
\hline Mean & & 1.2 & +0.9 & +2.0 & +1.1 & +0.5 & +0.2 & -0.1 & 2.2 & +0.1 & +0.1 & +0.2 & +0.3 & 0 & -0.2 \\
\hline
\end{tabular}


TABLE IV

Influence of carbohydrate deprivation on blood malic acid and plasma inorganic phosphorus concentrations following intravenous administration of hexoses in normal subjects

\begin{tabular}{|c|c|c|c|c|c|c|c|c|c|c|c|c|c|c|c|}
\hline \multirow{4}{*}{$\begin{array}{l}\text { Sub- } \\
\text { ject }\end{array}$} & \multirow{4}{*}{$\begin{array}{l}\text { Previous } \\
\text { diet }\end{array}$} & \multicolumn{7}{|c|}{ Blood malic acid ( $m g . / 100 \mathrm{ml}$. ) } & \multicolumn{7}{|c|}{ Plasma inorganic phosphorus ( $\mathrm{mg} . / 100 \mathrm{ml}$.) } \\
\hline & & \multirow{3}{*}{$\begin{array}{l}\text { Initial } \\
\text { concen- } \\
\text { tration }\end{array}$} & \multicolumn{6}{|c|}{ Change from initial concentration } & \multirow{3}{*}{$\begin{array}{l}\text { Initial } \\
\text { concen- } \\
\text { tration }\end{array}$} & \multirow{2}{*}{\multicolumn{6}{|c|}{$\begin{array}{c}\text { Change from initial concentration } \\
\text { Minutes after start of infusion }\end{array}$}} \\
\hline & & & \multicolumn{6}{|c|}{ Minutes after start of infusion } & & & & & & & \\
\hline & & & 30 & 60 & 90 & 120 & 150 & 180 & & 30 & 60 & 90 & 120 & 150 & 180 \\
\hline \multicolumn{16}{|c|}{ After glucose $(1 \mathrm{Gm} . / \mathrm{Kg}$. in $1 \mathrm{hr})}$. \\
\hline F. P. & Mixed & 0.15 & +0.01 & -0.01 & +0.02 & +0.02 & & -0.01 & 3.6 & -0.4 & -0.8 & -1.1 & -1.1 & & -1.6 \\
\hline R. B. & Mixed & 0.17 & +0.02 & -0.01 & -0.03 & 0 & +0.01 & -0.02 & 4.0 & -0.7 & -0.2 & -1.8 & -2.4 & -1.9 & -2.0 \\
\hline J. W. & Mixed & & & & & & & & 3.8 & -0.6 & -1.2 & -1.4 & -1.4 & -1.3 & -1.6 \\
\hline R. W. & Mixed & & & & & & & & 4.0 & -0.6 & -0.7 & -0.9 & -0.8 & -1.4 & -0.9 \\
\hline A. M. & Mixed & 0.14 & +0.04 & +0.04 & +0.02 & 0 & & 0 & 4.5 & -0.6 & -0.8 & -1.4 & -1.3 & -1.3 & -1.1 \\
\hline W. C. & Mixed & 0.13 & +0.03 & +0.02 & +0.04 & +0.03 & +0.01 & +0.02 & 4.2 & -0.4 & -0.9 & -1.4 & -1.6 & -1.3 & -1.3 \\
\hline Mean & & 0.15 & +0.02 & +0.01 & +0.01 & +0.01 & +0.01 & $\mathbf{0}$ & 4.0 & -0.6 & -1.1 & -1.3 & -1.4 & -1.4 & -1.4 \\
\hline F. P. & Fasting & 0.17 & 0 & $\mathbf{0}$ & & 0 & +0.02 & 0 & 4.1 & -0.3 & -0.9 & & -1.3 & -1.7 & -1.7 \\
\hline R. B. & Fasting & 0.15 & 0 & 0 & +0.04 & $\mathbf{0}$ & -0.01 & +0.03 & 3.2 & -0.7 & -1.3 & -1.5 & -1.4 & -0.9 & -1.4 \\
\hline J. W. & Fasting & & & & & & & & 3.8 & -0.6 & -0.8 & -1.3 & -1.1 & -1.4 & -1.3 \\
\hline R. W. & Fasting & & & & & & & & 4.5 & -0.6 & -1.3 & -1.7 & -1.3 & -1.0 & -0.7 \\
\hline A. M. & No $\mathrm{CHO}$ & 0.16 & +0.03 & +0.02 & +0.05 & +0.04 & +0.04 & +0.06 & 3.8 & -1.0 & -1.4 & -2.0 & -1.6 & -1.7 & -1.5 \\
\hline W. C. & No $\mathrm{CHO}$ & 0.17 & -0.01 & +0.02 & -0.01 & +0.01 & +0.02 & +0.03 & 3.4 & -0.1 & -0.6 & -1.0 & -1.0 & -1.5 & -1.4 \\
\hline Mean & & 0.16 & +0.01 & +0.01 & +0.02 & +0.01 & +0.02 & +0.03 & 3.8 & -0.6 & -1.0 & -1.5 & -1.3 & -1.4 & -1.3 \\
\hline \multicolumn{16}{|c|}{ After fructose $(1 \mathrm{Gm} . / \mathrm{Kg}$. in $1 \mathrm{hr})}$. \\
\hline F. P. & Mixed & 0.21 & +0.01 & $\mathbf{0}$ & -0.02 & -0.06 & & -0.06 & 4.5 & -0.8 & -0.7 & -1.1 & -1.1 & & -1.3 \\
\hline R. B. & Mixed & 0.17 & +0.04 & +0.06 & +0.02 & -0.02 & 0 & -0.01 & 4.0 & -0.6 & -0.6 & -0.7 & -0.7 & -1.0 & -1.1 \\
\hline J. W. & Mixed & & & & & & & & 3.8 & -1.1 & -0.9 & -0.4 & -0.6 & & -0.5 \\
\hline R. W. & Mixed & & & & & & & & 5.0 & -1.7 & -1.2 & -0.9 & -1.2 & -1.1 & -0.7 \\
\hline A. M. & Mixed & 0.14 & +0.01 & +0.04 & +0.01 & +0.02 & & -0.01 & 3.7 & -0.5 & -0.4 & -0.4 & -0.9 & & -0.5 \\
\hline W. C. & Mixed & 0.16 & +0.04 & +0.04 & +0.04 & +0.01 & -0.01 & +0.03 & 4.4 & -0.7 & -1.1 & -0.4 & -0.9 & -1.2 & -1.0 \\
\hline Mean & & 0.17 & +0.02 & +0.04 & +0.01 & -0.02 & 0 & -0.01 & 4.2 & -0.9 & -0.8 & -0.6 & -0.9 & -1.1 & -0.8 \\
\hline F. P. & Fasting & 0.14 & +0.01 & +0.03 & +0.02 & +0.01 & & $\mathbf{0}$ & 4.3 & -0.8 & -1.0 & -0.6 & +0.1 & & -1.0 \\
\hline R. B. & Fasting & 0.11 & +0.07 & +0.08 & +0.07 & +0.06 & +0.04 & +0.04 & 2.7 & -0.5 & -0.5 & -0.1 & +0.2 & -0.2 & -0.2 \\
\hline J.W. & Fasting & & & & & & & & 3.9 & -0.6 & -0.8 & -0.6 & -0.7 & -0.7 & -1.0 \\
\hline R. W. & Fasting & & & & & & & & 4.2 & -0.5 & -0.6 & -0.4 & -0.4 & -0.4 & -0.3 \\
\hline A. $\mathrm{M}$. & No $\mathrm{CHO}$ & 0.17 & 0 & +0.05 & -0.02 & +0.01 & & +0.01 & 3.7 & -0.2 & -0.6 & -0.5 & -1.1 & & -0.8 \\
\hline W. C. & No $\mathrm{CHO}$ & 0.15 & +0.03 & +0.07 & +0.02 & +0.01 & -0.01 & -0.02 & 3.7 & -0.7 & -0.9 & -0.6 & -0.5 & -0.8 & -0.6 \\
\hline Mean & & 0.14 & +0.03 & +0.06 & +0.02 & +0.02 & +0.01 & +0.01 & 3.8 & -0.6 & -0.7 & -0.5 & -0.4 & -0.5 & -0.6 \\
\hline
\end{tabular}

were compared to the mean changes at corresponding time intervals in the control tests, $\mathrm{p}$ was consistently greater than 0.05 . Glucose administration was associated with minimal increases in the blood malic acid concentration both before and after carbohydrate deprivation. In every instance glucose produced a fall in the level of plasma inorganic phosphorus; the average maximum decrease was $1.7 \pm 0.4 \mathrm{mg}$. per $100 \mathrm{ml}$. in the control tests and $1.6 \pm 0.2 \mathrm{mg}$. per $100 \mathrm{ml}$. after dietary carbohydrate restriction $(\mathrm{p}>0.5)$.

\section{Fructose tolerance tests}

In the control tests the blood fructose concentration reached an average maximum value of $89 \pm 10 \mathrm{mg}$. per $100 \mathrm{ml}$. and returned to the initial level by 150 or 180 minutes. In tests per- formed after two days of carbohydrate deprivation the fructose concentration reached an average maximum value of $91 \pm 8 \mathrm{mg}$. per $100 \mathrm{ml}$. ( $\mathrm{p}>$ 0.5 ). In one case the rise was $20 \mathrm{mg}$. per $100 \mathrm{ml}$. greater than in the control test, and in another case it was $12 \mathrm{mg}$. per $100 \mathrm{ml}$. less; in the remaining cases the maximum values attained in the two tests varied by less than $10 \mathrm{mg}$. per $100 \mathrm{ml}$. The rate of decline of the blood fructose concentration was similar to that observed in the control tests.

In three of the six cases, the blood glucose rise associated with fructose administration was greater after carbohydrate restriction than in the well-fed state, in one case it was similar, and in two cases it was less after carbohydrate deprivation. In all instances the return of the blood glu- 


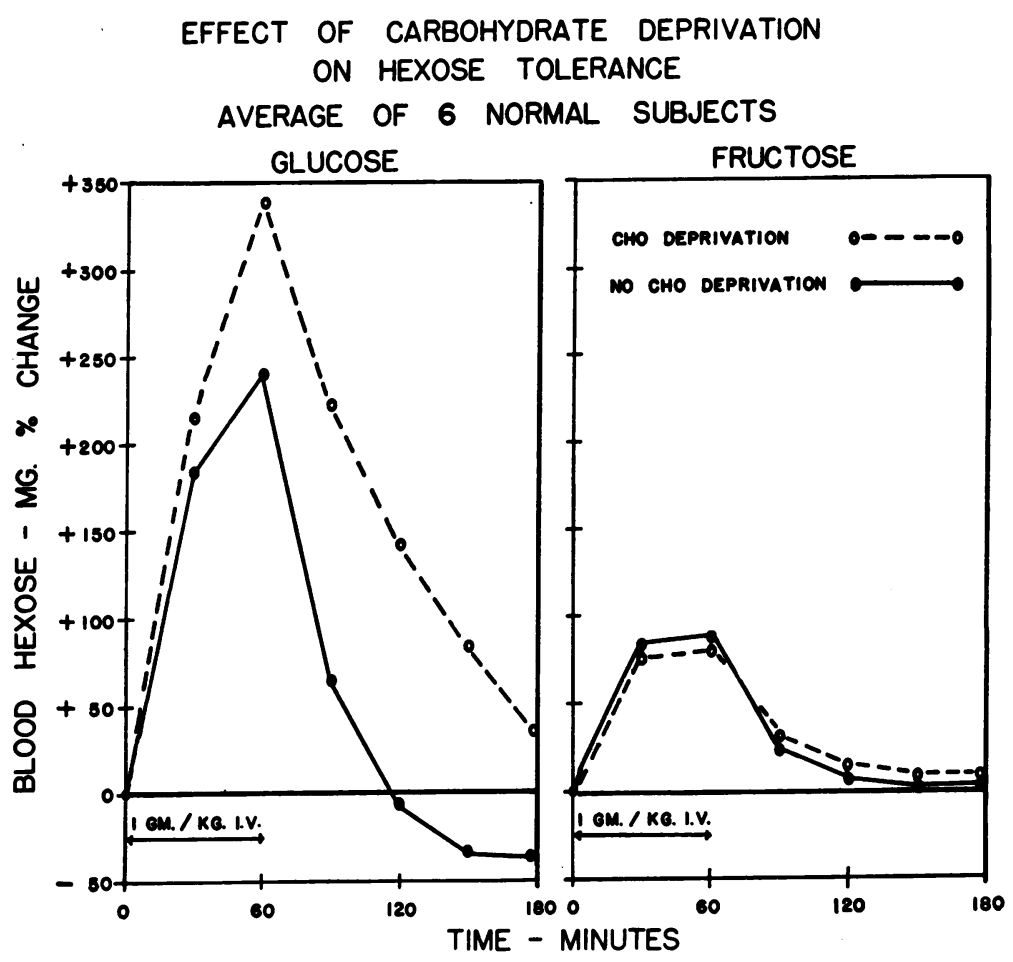

Fig. 1. Average Intravenous Glucose and Fructose Tolerance Curves of Six Normal Subjects Following a Normal Diet (Solid Lines) and Following Two Days of Fasting or a Carbohydrate-Free DIET (INTERRUPTEd LINES)

Blood hexose concentrations are plotted in terms of variation from the fasting level.

cose to the initial level was delayed after dietary restriction. The mean blood glucose changes were significantly different $(p<0.01)$ in the control and postrestriction tests at $90,120,150$, and 180 minutes.

Five of the six subjects showed a greater increase in blood pyruvic acid concentration after carbohydrate deprivation. The average maximum rise was $1.4 \pm 0.6 \mathrm{mg}$. per $100 \mathrm{ml}$. in the control test and $2.0 \pm 0.4$ per $100 \mathrm{ml}$. after dietary restriction $(0.05<\mathrm{p}<0.1)$.

During the fructose tolerance tests there was a small increase in the concentration of blood citric acid in each instance in contrast to the decrease produced by glucose administration; the magnitude of the increase was not altered in a consistent manner by dietary restriction, although the mean rise at 90 minutes was less $(0.05>p>0.02)$. There were small increases in the blood malic acid level during the tests performed both before and after carbohydrate deprivation; however, the mean changes from the initial level were not significantly different at any point in the control and postdeprivation tests. Fructose administration was accompanied by a fall in the concentration of plasma inorganic phosphorus in each instance. The average maximum phosphorus decrease was $1.2 \pm 0.3 \mathrm{mg}$. per $100 \mathrm{ml}$. in the control tests and $0.8 \pm 0.2 \mathrm{mg}$. per $100 \mathrm{ml}$. after dietary restriction $(0.02>p>0.01)$.

\section{DISCUSSION}

The results of these studies confirm previous observations that dietary carbohydrate deprivation decreases the rate of removal of administered glucose from the blood. Under the same circumstances, the rate of removal of administered fructose is not measurably altered. These findings afford further evidence that in man the predominant pathway for glucose metabolism differs from the pathway for fructose metabolism. They sug- 
gest that the metabolic defect induced by carbohydrate deprivation involves the pathway for glucose utilization without impairing fructose metabolism. Certain metabolic derangements have been demonstrated in liver slices from fasted rats. Wyshak and Chaikoff (23) reported that the conversion of glucose to $\mathrm{CO}_{2}$, glycogen, and fatty acids was depressed in liver slices from fasted rats; $\mathrm{CO}_{2}$ and glycogen were formed from fructose at a normal rate, although lipogenesis from this hexose was impaired. These investigators suggested that the defect in glucose utilization probably occurred at the glucokinase reaction, while the phosphorylation of fructose was under the influence of a separate enzyme (fructokinase) and was not altered by fasting. Our results are consistent with this hypothesis, although a defect in glucose metabolism at any step between glucose transport and the triose phosphate level could account for the observed difference in the effect of carbohydrate deprivation on the disappearance of glucose and fructose from the blood. Kuyper (24) found that the fructokinase activity was diminished in liver slices from fasted rats; however, our studies do not indicate a significant alteration in the overall rate of fructose removal such as might be observed if the phosphorylation of fructose were impaired by carbohydrate deprivation in man.

The fact that results similar to those of the present study were obtained when glucose and fructose were administered to diabetic subjects (10) suggests the possibility that a lack of insulin effect may be involved in the changes induced by carbohydrate deprivation. The available data regarding the role of insulin in starvation diabetes are conflicting. A diminished insulin effect might be due to a decreased supply of endogenous insulin or to the presence of insulin antagonists. Best, Haist, and Ridout (25) observed a decrease in the insulin content of the pancreas of fasted rats. However, Bergman and Drury (26) found that rabbits which had been fasted prior to evisceration exhibited a diminished rate of glucose utilization in comparison to non-fasted eviscerated rabbits; since both groups of animals were depancreatized, this phenomenon apparently did not depend upon differences in the amount of available insulin at the time that glucose utilization was measured. Himsworth (27) reported that the insulin sensitivity of normal human subjects was reduced by a decrease in dietary carbohydrate, and Mirsky and Perisutti (28) found that the insulin-inactivating capacity of rat liver slices was increased by fasting. However, the importance of insulin in the production of the metabolic defects associated with carbohydrate deprivation remains unsettled.

There is also the possibility that the metabolic changes associated with carbohydrate deprivation are related to increased adrenal cortical activity. An impairment of glucose tolerance with no alteration in the rate of fructose removal has been described in normal men following a single dose of cortisone (11). Engel's observation (29) that glucose tolerance is unimpaired by a 48 hour period of fasting or low carbohydrate intake in patients with adrenal insufficiency also suggests that the adrenal cortex may be involved. In experimental animals, complete inanition (30) or a high protein diet (31) produce adrenal cortical hypertrophy, but the effect of a low carbohydrate diet per se has not been studied adequately. In Cushing's syndrome (32-34) and in patients receiving adrenocorticotropic hormone (ACTH) or adrenal cortical steroids (33-36) the concentration of blood pyruvic acid is frequently elevated in the postabsorptive state. It is of interest in this regard that in 9 of our 12 paired experiments the concentration of blood pyruvic acid in the postabsorptive state was higher after carbohydrate deprivation than in the control test. In Cushing's syndrome an abnormally high rise in blood pyruvic acid has been observed after fructose infusion (37) ; fructose administration produced a greater rise in the blood pyruvic acid concentration after carbohydrate deprivation than in the control test in five of our six subjects. Abnormally great and prolonged elevations of the blood pyruvic acid concentration have been reported after glucose administration in Cushing's syndrome $(32,33)$, and the same phenomenon has been observed in patients receiving ACTH or adrenal cortical steroids $(33,34)$. However, in the present experiments such a pyruvic acid change was recorded in only one of six subjects when glucose was administered after carbohydrate deprivation. Because more direct measurements of adrenal cortical function in man during a relatively brief period of carbohydrate deprivation 
are not available, the relationship of the adrenal cortex to the observed metabolic changes cannot be evaluated accurately.

Engel (29) has reported that the glucose tolerance test is not altered by fasting in the patient with pituitary insufficiency, and Himsworth and Scott (38) found that glucose tolerance was not impaired by a low carbohydrate diet in the hypophysectomized rabbit. Recant (39) investigated a respiratory quotient (R.Q.) depressing factor of anterior pituitary origin. This substance inhibited the rise in R.Q. which occurred when glucose or hexose diphosphate were added to a rat diaphragm preparation but did not inhibit the R.Q. rise produced by 3-phosphoglyceric acid. A similar R.Q. depressing factor was demonstrated in the serum of fasted normal rats but was absent from the serum of fasted hypophysectomized rats and normal rats on an adequate diet. Although these observations suggest that the anterior pituitary may be involved in the production of the metabolic changes associated with dietary carbohydrate deprivation, the results of other investigators are not in agreement. For example, two groups of workers $(40,41)$ have altered the glucose tolerance curves of hypophysectomized dogs by reducing the carbohydrate content of the diet. As in the case of the other endocrine glands, sufficient information is not available to assess the role of the anterior pituitary in the production of the metabolic changes of starvation diabetes.

From a teleological viewpoint, it is of interest that the metabolism of the most important carbohydrate fuel of the body, glucose, is impaired in so many conditions, including starvation, diabetes mellitus, and stress; while the utilization of fructose, which apparently plays a relatively minor role quantitatively in the normal body economy, proceeds at an unchanged rate under the same circumstances. In starvation, the net impairment of glucose utilization may represent a mechanism for the maintenance of an adequate supply of glucose for the central nervous system which is dependent upon this particular hexose.

\section{SUMMARY}

1. Intravenous glucose and fructose tolerance tests were performed in six normal subjects before and after two days of dietary carbohydrate deprivation.
2. The rate of removal of administered glucose from the blood was diminished after carbohydrate deprivation, while fructose disappeared at a normal rate.

3. These results afford further evidence that the metabolism of fructose differs from the metabolism of glucose in man.

\section{ACKNOWLEDGMENTS}

We wish to express our appreciation to Helen Banta Peterson, dietitian for the Metabolic Research Division, for aid in planning and preparing the experimental diets, to Naomi Nickerson and Elo Merik for technical assistance, and to the medical students and house officers who served as subjects for these studies.

\section{REFERENCES}

1. Peters, J. P., Starvation diabetes, the reason for the use of glucose in the treatment of diabetic acidosis. Yale J. Biol. \& Med., 1944-45, 17, 705.

2. Nagasuye, S., Experimentelle Untersuchungen über die Assimilation der Lävulose, Galaktose, und der Glykose bei Hunger und Eiweissfettdiät. J. Biochem. (Japan), 1925, 5, 449.

3. Reinhold, J. G., and Karr, W. G., Carbohydrate utilization. II. Rate of disappearance of various carbohydrates from the blood. J. Biol. Chem., 1927, 72, 345.

4. Meyer, P. F., Glycogen storage and laevulose tolerance. J. Physiol., 1933-34, 80, 480.

5. Goldblatt, M. W., Observations on the effect of various carbohydrates on the ketosis of starvation in human subjects. Biochem. J., 1925, 19, 948.

6. Potick, D., Dieta previa y tolerancia a la levulosa en el perro normal e hipofisoprivo. Rev. Soc. argent. de biol., 1943, 19, 191.

7. Cori, G. T., Ochoa, S., Slein, M. W., and Cori, C. F., The metabolism of fructose in liver. Isolation of fructose-1-phosphate and inorganic pyrophosphate. Biochim. et biophys. acta, 1951, 7, 304.

8. Chaikoff, I. L., Metabolic blocks in carbohydrate metabolism in diabetes. Harvey Lect. (19511952), 1953, 47, 99.

9. Hers, H. G., and Kusaka, T., Le métabolisme du fructose-1-phosphate dans le foie. Biochim. et biophys. acta, 1953, 11, 427.

10. Miller, M., Drucker, W. R., Owens, J. E., Craig, J. W., and Woodward, H., Jr., Metabolism of intravenous fructose and glucose in normal and diabetic subjects. J. Clin. Invest., 1952, 31, 115.

11. Papper, S., Saxon, L., Prout, T. E., and Alpert, H. C., The effects of cortisone on the fructose and glucose tolerance tests of normal men. J. Lab. \& Clin. Med., 1956, 48, 13.

12. Drucker, W. R., Miller, M., Craig, J., Jefferies, W. McK., Levey, S., and Abbott, W. E., A comparison of the effect of operation on glucose and 
fructose metabolism in Surgical Forum. Philadelphia, W. B. Saunders Company, 1953, p. 548.

13. Drucker, W. R., Costley, C., Stults, R., Gross, G., Holden, W., Miller, M., Craig, J., and Woodward, $H$., The effect of anesthesia on intermediary carbohydrate metabolism (abstract). Clin. Research Proc., 1955, 3, 202.

14. Drucker, W. R., Miller, M., Abbott, W. E., Craig, J. W., Jefferies, W. M., Levey, S., and Woodward, $H$., The effect of stress on glucose and fructose metabolism (abstract). J. Lab. \& Clin. Med., 1952, 40, 794.

15. Somogyi, M., Determination of blood sugar. J. Biol. Chem., 1945, 160, 69.

16. Higashi, A., and Peters, L., A rapid colorimetric method for the determination of inulin in plasma and urine. J. Lab. \& Clin. Med., 1950, 35, 475.

17. Friedemann, T. E., and Haugen, G. E., Pyruvic acid. II. The determination of keto acids in blood and urine. J. Biol. Chem., 1943, 147, 415.

18. Natelson, S., Pincus, J. B., and Lugovoy, J. K., Microestimation of citric acid; a new colorimetric reaction for pentabromoacetone. J. Biol. Chem., 1948, 175, 745.

19. Taussky, H. H., and Shorr, E., A microcolorimetric method for the determination of citric acid. J. Biol. Chem., 1947, 169, 103.

20. Hummel, J. P., The fluorometric determination of malic acid. J. Biol. Chem., 1949, 180, 1225.

21. Fiske, C. H., and Subbarow, Y., The colorimetric determination of phosphorus. J. Biol. Chem., 1925, 66, 375.

22. Eichler, O., and Hindemith, H., Versuche zur Methodik der Bestimmung der Acetonkörper, insbesondere der B Oxybuttersäure. Biochem. Ztschr., 1943, 314, 73.

23. Wyshak, G. H., and Chaikoff, I. L., Metabolic defects in liver of fasted rats as shown by utilization of $\mathrm{C}^{14}$-labeled glucose and fructose. J. Biol. Chem., 1953, 200, 851.

24. Kuyper, C., Rat liver fructokinase as an adaptive enzyme (abstract). Arch. internat. de physiol., 1954, 62, 566.

25. Best, C. H., Haist, R. E., and Ridout, J. H., Diet and the insulin content of the pancreas. J. Physiol., 1939, 97, 107.

26. Bergman, H. C., and Drury, D. R., Effect of feeding and fasting on sugar utilization of eviscerated rabbits. Proc. Soc. Exper. Biol. \& Med., 1937-38, 37,414 .
27. Himsworth, H. P., The dietetic factor determining the glucose tolerance and sensitivity to insulin of healthy men. Clin. Sc., 1935, 2, 67.

28. Mirsky, I. A., and Perisutti, G., The inactivation of insulin by liver slices of the rat. Endocrinology, 1953, 52, 698.

29. Engel, F. L., The endocrine control of metabolism. Bull. New York Acad. Med., 1953, 29, 175.

30. Tepperman, J., Engel, F. L., and Long, C. N. H., A review of adrenal cortical hypertrophy. Endocrinology, 1943, 32, 373.

31. Tepperman, J., Engel, F. L., and Long, C. N. H., Effect of high protein diets on size and activity of the adrenal cortex in the albino rat. Endocrinology, 1943, 32, 403.

32. Hills, O. W., Power, M. H., and Wilder, R. M., Diabetes mellitus and Cushing's syndrome: concentrations of lactate and pyruvate in blood after ingestion of glucose. Diabetes, 1952, 1, 351.

33. Kerppola, W., Accumulation of pyruvic acid in the blood during treatment with cortisone or ACTH, and in Cushing's syndrome. Acta med. Scandinav., 1953, 145, 357.

34. Frawley, T. F., The role of the adrenal cortex in glucose and pyruvic acid metabolism in man including the use of intravenous hydrocortisone in acute hypoglycemia. Ann. New York Acad. Sc., 1955, 61, 464.

35. Gitelson, S., The effect of ACTH and cortisone on the blood pyruvic acid level. Acta endocrinol., 1954, 15, 225.

36. Lövgren, O., The effect of cortisone and ACTH treatment on certain carbohydrate metabolites. Acta endocrinol., 1952, 9, 421.

37. Drucker, W. R., Craig, J. W., Miller, M., and Woodward, H., Jr. Unpublished observations.

38. Himsworth, H. P., and Scott, D. B. McN., The relation of the hypophysis to changes in sugar tolerance and insulin sensitivity induced by changes of diet. J. Physiol., 1938, 91, 447.

39. Recant, L., Pituitary respiratory-quotient depressing factor (abstract). J. Clin. Invest., 1952, 31, 656.

40. Weichselbaum, T. E., Heinbecker, P., and Somogyi, M., Effect of diet on glucose tolerance of normal and hypophysectomized dogs. Proc. Soc. Exper. Biol. \& Med., 1937, 36, 802.

41. Foglia, V. G., and Potick, D., Dieta previa y tolerancia a la glucosa del perro hipofisoprivo. Rev. Soc. argent. de biol., 1941, 17, 289. 